Article

\title{
Gene Characterization and Enzymatic Activities Related to Trehalose Metabolism of In Vitro Reared Trichogramma dendrolimi Matsumura (Hymenoptera: Trichogrammatidae) under Sustained Cold Stress
}

\author{
Xin Lü *(D), Shi-chou Han, Zhi-gang Li, Li-ying Li and Jun Li * \\ Guangdong Key Laboratory of Animal Conservation and Resource Utilization, \\ Guangdong Public Laboratory of Wild Animal Conservation and Utilization, Institute of Zoology, \\ Guangdong Academy of Sciences, 105 Xingang Road West, Guangzhou 510260, China; \\ hansc@giabr.gd.cn (S.-c.H.); leegdei@163.com (Z.-g.L.); liying132@163.com (L.-y.L.) \\ * Correspondence: greenhopelv@163.com (X.L.); junl@giabr.gd.cn (J.L.)
}

Received: 23 September 2020; Accepted: 4 November 2020; Published: 7 November 2020

Simple Summary: Trehalose is a non-reducing disaccharide that presents in a wide variety of organisms, where it serves as an energy source or stress protectant. Trehalose is the most characteristic sugar of insect hemolymph and plays a crucial role in the regulation of insect growth and development. Trichogramma species are economically important egg parasitoids, which are being mass-produced for biological control programs worldwide. Many Trichogramma species could be mass reared on artificial mediums (not insect eggs), in which components contain insect hemolymph and trehalose. These in vitro-reared parasitoid wasps were strongly affected by cold storage, but prepupae could be successfully stored at $13^{\circ} \mathrm{C}$ for up to 4 weeks. The aims of the present study were to determine the role of trehalose and the relationship between trehalose and egg parasitoid stress resistance. Our study revealed that (1) trehalose regulated the growth under sustained cold stress; (2) prepupal stage is a critical developmental period and $13{ }^{\circ} \mathrm{C}$ is the cold tolerance threshold temperature; (3) in vitro reared Trichogramma dendrolimi could be reared at temperatures of $16{ }^{\circ} \mathrm{C}, 20^{\circ} \mathrm{C}$, and $23^{\circ} \mathrm{C}$ to reduce rearing costs. This finding identifies a low cost, prolonged development rearing method for T. dendrolimi, which will facilitate improved mass rearing methods for biocontrol.

\begin{abstract}
Trichogramma spp. is an important egg parasitoid wasp for biocontrol of agriculture and forestry insect pests. Trehalose serves as an energy source or stress protectant for insects. To study the potential role of trehalose in cold resistance on an egg parasitoid, cDNA for trehalose-6-phosphate synthase (TPS) and soluble trehalase (TRE) from Trichogramma dendrolimi were cloned and characterized. Gene expressions and enzyme activities of TdTPS and TdTRE were determined in larvae, prepupae, pupae, and adults at sustained low temperatures, $13^{\circ} \mathrm{C}$ and $16^{\circ} \mathrm{C}$. TdTPS and TdTRE expressions had similar patterns with higher levels in prepupae at $13^{\circ} \mathrm{C}$ and $16^{\circ} \mathrm{C}$. TdTPS enzyme activities increased with a decrease of temperature, and TdTRE activity in prepupae decreased sharply at these two low temperatures. In vitro reared T. dendrolimi could complete entire development above $13{ }^{\circ} \mathrm{C}$, and the development period was prolonged without cold injury. Results indicated trehalose might regulate growth and the metabolic process of cold tolerance. Moreover, $13^{\circ} \mathrm{C}$ is the cold tolerance threshold temperature and the prepupal stage is a critical developmental period for in vitro reared T. dendrolimi. These findings identify a low cost, prolonged development rearing method, and the cold tolerance for T. dendrolimi, which will facilitate improved mass rearing methods for biocontrol.
\end{abstract}

Keywords: trehalase; trehalose metabolism; in vitro rearing; cold stress; Trichogramma 


\section{Introduction}

Sugars are used for energy production and are stored as glycogen in the body fat, or as trehalose in the hemolymph [1-3]. Trichogramma are egg parasitoid wasps that obtain diverse nutrients, including sugars, from their host eggs during development. Trichogramma dendrolimi Matsumura is an important biological control agent that has been mass produced on eggs of Corcyra cephalonica (Stainton) and Antheraea pernyi (Guérin-Méneville) for biological control programs in China [4,5]. Artificial host eggs are now used to mass produce T. dendrolimi [6,7]. Lü et al. [8-10] developed an artificial medium containing trehalose for the continuous rearing of T. dendrolimi and revealed that trehalose was an essential ingredient of the artificial media. Biochemical characteristics, including trehalose content and trehalase activity in T. dendrolimi, continuously reared on artificial medium (in vitro) versus those reared on A. pernyi eggs (in vivo), were also studied [11]. The quality of in vitro reared T. dendrolimi was strongly affected by cold storage, but prepupae could be successfully stored at $13^{\circ} \mathrm{C}$ for up to 4 weeks [12].

The developmental temperature threshold can vary, not only among insects, but also among populations $[13,14]$. Trichogramma spp. show different reactions to low temperatures when reared on different hosts or media [12,13]. For T. dendrolimi, the developmental threshold temperature was different among geographical populations and hosts: $10.34{ }^{\circ} \mathrm{C}$ for south population reared on Philosamia cynthia ricini [13]; $10.1^{\circ} \mathrm{C}$ for the south population reared on C. cephalonica [14]; $5.34^{\circ} \mathrm{C} / 5.1^{\circ} \mathrm{C}$, $5.82{ }^{\circ} \mathrm{C} / 5.42{ }^{\circ} \mathrm{C}, 11.03^{\circ} \mathrm{C} / 14.83^{\circ} \mathrm{C}$, and $12.37^{\circ} \mathrm{C} / 11.58^{\circ} \mathrm{C}$ for the north population (egg, larva, prepupa and pupa) reared on $A$. pernyi $[15,16]$. The north population reared on $A$. pernyi was unable to complete the entire development (stopped developing at prepupal stage) at $10^{\circ} \mathrm{C}$, but was able to complete the entire development above $15^{\circ} \mathrm{C}$ [15]. Compared with the in vivo (on A. pernyi) reared Trichogramma, in vitro (on artificial medium) reared Trichogramma of the south population was more affected by cold storage [12]. All of these experimental populations have been lab adapted. Limited information is available about inducing cold stress on the lab adapted strain of this particular insect species, and molecular mechanisms of trehalose metabolism, or the relationship between trehalose and egg parasitoid stress resistance [17-21]. Based on the facile sampling and reproducibility of the condition of in vitro reared T. dendrolimi, trehalose metabolism related enzymes were explored by investigating their changes in gene expression and corresponding enzyme activities to study the effect of cold stress conditions on egg parasitoids.

Trehalose is involved in the regulation of parasitoid growth and development. The disaccharide sugar trehalose serves as an energy source or stress protectant for parasitoids [22,23]. It promotes longevity, fecundity $[24,25]$, and cold tolerance $[18,26,27]$, and provides' energy needed to search for, and parasitize, hosts [28]. Trehalose is synthesized by trehalose-6-phosphate synthase (TPS, EC 2.4.1.15) and trehalose-6-phosphate phosphatase (TPP, EC 3.1.3.12) in the body fat, and is hydrolyzed by trehalase (TRE, EC 3.2.1.28) to yield two glucose molecules in the hemolymph $[19,20,29-31]$. The activity of these three enzymes also affects insect physiology and development. Trehalose and trehalase are closely associated with growth and development throughout insect life cycles [2,23]. However, we should notice the adult yields and quality of in vitro rearing some parasitoids (e.g., the tachinid Exorista larvarum) did not drop when the artificial medium without insect material, which trehalose has been replaced with sucrose and sucrose, was even deleted, without drops in adult yields [32,33].

TPS and TPP genes have two functional conserved domains similar to yeast genes and are homologs of yeast Tps1 (Ots A) and Tps2 (Ots B), respectively [34]. In insects, TPS is a fused gene [35] and two exons are involved in encoding trehalose synthetase [36]. Trehalase catalyses, the irreversible hydrolysis of trehalose to glucose, which is the only known pathway of trehalose utilization [2]. TRE is essential for energy metabolism and is important in insect growth and molting [37]. Trehalose may function as a cryoprotectant to stabilize proteins at low temperatures [2,18], and may also protect insects from external interference, assist in successful completion of metamorphosis, and aid survival in adverse environments [38]. In addition, trehalose is important in the regulation of insect growth and development and serves as an energy source and stress protectant $[19,38-41]$. 
TPS has been cloned, characterized, and purified from many insect species. It was first cloned from Drosophila melanogaster [42]. TRE has been identified in insect species, such as Rhodnius prolixus, Nilaparvata lugens, Spodoptera exigua, Omphisa fuscidentalis, and Harmonia axyridis [19,30,43-46]. Although TPS and TRE are important key enzymes for many insects, in parasitoid wasps, only the trehalase cDNA from Pimpla hypochondriaca has been cloned [47]. No trehalose metabolism genes in Trichogramma, or even in any egg parasitoids, have been characterized. To understand the role of trehalose in the cold resistance of in vitro reared T. dendrolimi, two genes (TdTPS and TdTRE) were identified, and cloned the full-length cDNA of $T$. dendrolimi reared on artificial medium using transcriptome data from T. dendrolimi reared on eggs of $A$. pernyi. The changes in gene expression and corresponding enzyme activities in four developmental stages (larva, prepupa, pupa, and adult) as each stage developed at low temperatures were also recorded. The trehalose metabolism in the life cycle of T. dendrolimi was systematically investigated in relation to cold hardiness.

\section{Materials and Methods}

\subsection{Insects}

Trichogramma dendrolimi were provided by Engineering Research Center of Natural Enemies, Institute of Biological Control, Jilin Agricultural University, Changchun, China. In the laboratory, T. dendrolimi stock cultures were reared on eggs of A. pernyi as a factitious host. Rearing conditions were $27^{\circ} \mathrm{C} \pm 1,75 \% \pm 5$ relative humidity $(\mathrm{RH})$ and a $16: 8 \mathrm{~h}(\mathrm{~L}: \mathrm{D})$ photoperiod.

\subsection{Preparation of Artificial Medium and Insect Rearing}

The artificial medium used in this study was the modified artificial medium developed by Lü et al. [9]. It comprised $3 \mathrm{~mL}$ of the pupal hemolymph of A. pernyi, $2.5 \mathrm{~mL}$ egg yolk, $1 \mathrm{~mL} 10 \%$ malted milk solution, $1 \mathrm{~mL}$ Neisenheimer's salt solution, $0.1 \mathrm{~g}$ trehalose (Sigma, St. Louis, MO, USA), and $1.5 \mathrm{~mL}$ sterile water. The preparation of artificial egg cards was done as described by Lü et al. [11].

Artificial egg cards were placed in a plastic tray $(20 \mathrm{~cm} \times 10 \mathrm{~cm} \times 3 \mathrm{~cm})$ for $24 \mathrm{~h}$ exposure to T. dendrolimi adults of the same batch. Parasitoids of both sexes were released in the trays using a 6:1 ratio of parasitoids to artificial eggs. Sex ratios were approximately 8:1 (female:male) in all three replicates (one tray corresponded to one replicate). Trays were placed in climatic incubators (Yamato, Tokyo, Japan) set at $27^{\circ} \mathrm{C} \pm 1,75 \% \pm 5 \mathrm{RH}$, and a 16:8 $\mathrm{h}$ (L:D) photoperiod. After $24 \mathrm{~h}$ of exposure, the wasps were removed, and the egg cards were transferred to the temperature treatments [9].

\subsection{Experimental Set-Up, Sample Collection, and Biological Parameters Assessment}

In a pre-experiment, in vitro reared $T$. dendrolimi were unable to complete the entire development (from egg to adult) at $10{ }^{\circ} \mathrm{C}$, and stopped developing at prepupal or pupal stages. The optimum storage condition for these parasitoid wasps are prepupae that can be stored at $13{ }^{\circ} \mathrm{C}$ for up to 4 weeks without affecting reproductive quality [12]. The present experiment had two factors: temperature ( $13{ }^{\circ} \mathrm{C} \pm 1$ (optimum storage temperature), $16{ }^{\circ} \mathrm{C} \pm 1$ (above the optimum storage temperature) and $27^{\circ} \mathrm{C} \pm 1$ (optimum development temperature)), and developmental stage (larva, prepupa, pupa, and adult). In a preliminary experiment, based on the transparency of the egg cards, they can be easily monitored daily for parasitoid development using a binocular microscope. T. dendrolimi developing to new larvae, prepupae, pupae, or adults were collected on ice and maintained at $-80{ }^{\circ} \mathrm{C}$ for gene expression and biochemical assessments.

In the follow-up rearing experiment, to investigate the developmental quality of $T$. dendrolimi reared on artificial medium at different temperatures $\left(27^{\circ} \mathrm{C} \pm 1,23{ }^{\circ} \mathrm{C} \pm 1,20^{\circ} \mathrm{C} \pm 1,16{ }^{\circ} \mathrm{C} \pm 1\right.$, and $13{ }^{\circ} \mathrm{C} \pm 1$ ), the developmental durations (from oviposition to adult emergence) of the eggs, larvae, prepupae, and pupae, number of male adults and total adults observed per egg card were examined. Pupation rate, adult emergence rate (based on pupal numbers), numbers of normal adults produced 
(i.e., adults not having an enlarged abdomen and/or unexpanded wings) and the adult sex ratio (female proportion) was calculated as follows:

- $\quad$ Pupation rate $(\%)=($ number of pupae/total number of larvae observed per egg card $) \times 100$.

- Emergence rate $(\%)=($ number of adults/(number of adults + dead pupae + dead larvae $)) \times 100$.

- Number of normal adults $=$ total number of normal adults observed to emerge from three replicates (egg cards)/3.

- Female proportion $(\%)=($ total number of adults observed - number of male adults observed $) /$ total number of adults observed $\times 100$.

\subsection{Total RNA Extraction and Cloning of the Full-Length cDNA}

Total RNA was extracted from T. dendrolimi adults using a TransZol Up Plus RNA Kit (TransGen, Beijing, China). The RNA integrity and concentration were checked by agarose gel electrophoresis and spectrophotometry (NanoDrop2000, Wilmington, DE, USA), respectively. The fragments of TdTPS and TdTRE were obtained by transcriptome sequencing of T. dendrolimi (Hiseq 2000, Illumina, Beijing, China). Full-length sequences of TPS and TRE were obtained by $5^{\prime}$ and $3^{\prime}$ rapid amplification of cDNA ends (RACE) with the SMART ${ }^{\mathrm{TM}}$ RACE Kit (TaKaRa, Tokyo, Japan), according to manufacturer instructions. $5^{\prime}$ and $3^{\prime}$ RACE were performed by nested PCR including Universal Primer Mix (UPM) and Nested Universal Primer (NUP) along with gene-specific primers (GSP) (Table 1). The PCR conditions were as follows: initial at $94{ }^{\circ} \mathrm{C}$ for $5 \mathrm{~min}, 32$ cycles of $30 \mathrm{~s}$ at $94{ }^{\circ} \mathrm{C}, 30 \mathrm{~s}$ at $60{ }^{\circ} \mathrm{C}, 2 \mathrm{~min}$ at $72{ }^{\circ} \mathrm{C}$, and a final extension at $72{ }^{\circ} \mathrm{C}$ for $10 \mathrm{~min}$. The products were examined by agarose gel electrophoresis, purified using a SanPrep Column DNA Gel Extraction Kit (Sangon, Shanghai, China), ligated into a Pucm-T vector (Sangon, Shanghai, China), and sequenced by Sanger's method.

Table 1. Primers sequences used for real-time PCR.

\begin{tabular}{|c|c|c|c|}
\hline Gene & Primer Name & Sequence $\left(5^{\prime}-3^{\prime}\right)$ & Usage \\
\hline \multirow{14}{*}{ TdTPS } & 5Race-R & TTTTTTTTTTTTTTTTTTTTTTTTTVN & \\
\hline & UPM-long & CTAATACGACTCACTATAGGGCAAGCAGTGGTATCAACGCAGAGT & \\
\hline & UPM-short & CTAATACGACTCACTATAGGGC & \\
\hline & $\begin{array}{l}\text { BD SMART II }{ }^{\mathrm{TM}} \mathrm{A} \\
\text { Oligonucleotide }\end{array}$ & AAGCAGTGGTATCAACGCAGAGTACGCGGG & $\begin{array}{l}\text { First full length cDNA synthesis } \\
\text { for } 5^{\prime} \text { cDNA amplification }\end{array}$ \\
\hline & 3’NUP-R & AAGCAGTGGTATCAACGCAGAGT & \\
\hline & 3Race-R & AAGCAGTGGTATCAACGCAGAGTACT(30)VN & $\begin{array}{l}\text { First full length cDNA synthesis } \\
\text { for } 3^{\prime} \mathrm{cDNA} \text { or CDS amplification }\end{array}$ \\
\hline & $5 \mathrm{r}-\mathrm{TPS}-1 \mathrm{R}$ & AGTGGTCCGCGATGAAGGTCGC & \\
\hline & $5 \mathrm{r}-\mathrm{TPS}-2 \mathrm{R}$ & CCCAGATGCCATTTCCATTGATGAC & $\begin{array}{c}\text { 5' cDNA } \\
\text { amplification }\end{array}$ \\
\hline & cTPS-F & TCGGGCAGYATGATYGTCGT & \\
\hline & cTPS-R & TGCCTCTCKACCCAYTTGAGCAT & \\
\hline & cTPS-1R & TGTCTGTTACGTGGTCTGGGTGA & cds amplification \\
\hline & 3r-TPS-R & CCACCACGACAACTCCTCGA & $\begin{array}{c}3^{\prime} \text { cDNA } \\
\text { amplification }\end{array}$ \\
\hline & qTPS-F & AATGGAAATGGCATCTGGGTC & \\
\hline & qTPS-R & AGCAGCCGTTGTAGTACGAGTC & qRT-PCR \\
\hline \multirow{7}{*}{ TdTRE } & 5r-TRE-1R & GTACAGCTCGTCCTTGTCATCG & \\
\hline & $5 r$-TRE-2R & CGCTAATTGTATCGTCTTTAGTAGTTCG & $\begin{array}{c}5^{\prime} \text { cDNA } \\
\text { amplification }\end{array}$ \\
\hline & CTRE-F & TTCCTGAAACAGTAGTMTTTAGTCG & \\
\hline & cTRE-R & CTCAAAAGTACGTTGTCCAAATAGAT & cds amplification \\
\hline & 3r-TRE-R & GTTGATATCAAGAAACCAACGAACG & $\begin{array}{c}3^{\prime} \text { cDNA } \\
\text { amplification }\end{array}$ \\
\hline & qTRE-F & AAGCGAAAGCCAAGCAAGGT & \\
\hline & qTRE-R & TGATACACGGGGTCACGAATAC & qRT-PCR \\
\hline
\end{tabular}

UPM, Universal Primer Mix; NUP, Nested Universal Primer; F, Forward; R, Reverse. 


\subsection{Sequence Analysis}

The amino acid sequences of T. dendrolimi in the fasta format was used to query the sequence database of the National Center for Biotechnology Information (NCBI) to identify proteins with primary sequence similarity to TdTPS and TdTRE. Multiple sequence alignment was constructed using MEGA 7 [48] with the CLUSTAL V method [49,50]. Phylogenetic trees were constructed using the neighbor-joining (NJ) method [51]. D. melanogaster was used as the out-group, and the stability of the tree was assessed via bootstrapping with $>1000$ replicates.

\subsection{Expression of TdTPS and TdTRE}

Total RNA was extracted from $0.1 \mathrm{~g}$ of $T$. dendrolimi at larval, prepupal, pupal, and adult stages using a TransZol Up Plus RNA Kit (TransGen, Beijing, China). First-strand cDNA was synthesized from $1 \mu \mathrm{g}$ total RNA using a FastQuant RT Kit With gDNase (Tiangen, Beijing, China).

Steps to construct linearized plasmid standards were as described previously with some modifications [52]. First, products TdTPS and TdTRE were extracted and purified with an agarose gel Extraction Kit (Sangon, Shanghai, China). Second, each gene was cloned separately using the Pucm-T Cloning Vector Kit (Sangon), according to the manufacturer instructions. Third, positive clones screened by PCR were processed for plasmid isolation using a Plasmid Extraction \& Purification Kit (Sangon) and confirmed by Sanger sequencing (Sangon). Fourth, plasmids were completely linearized by EcoR I digestion for $4.5 \mathrm{~h}$ at $37^{\circ} \mathrm{C}$ and confirmed by checking band patterns in the agarose gel. Fifth, linearized plasmids were quantified using a NanoDrop2000 spectrophotometer (NanoDrop), and copy numbers were calculated for all standards by the following formula [53]:

$$
\text { Copies } / \mu \mathrm{L}=\frac{\left(6.02 \times 10^{23} \text { copies }\right) \times(\text { plasmid concentration } \mathrm{g} / \mu \mathrm{L})}{(\text { number of bases }) \times(660 \text { daltons } / \text { base })}
$$

Finally, the standard DNA (template) was prepared in a dilution series from $10^{-3}$ to $10^{-10}$ (copies $/ 5 \mu \mathrm{L}$ ) for qPCR. qPCR was performed using a SYBR Green Mix Kit (Tiangen, Beijing, China) to measure the cycle number $(\mathrm{Ct})$ of each dilution in duplicate. Each PCR reaction was mixed with $10 \mu \mathrm{L}$ SYBR Green Mix, $6 \mu \mathrm{L}$ dd $\mathrm{H}_{2} \mathrm{O}, 2 \mu \mathrm{L}$ cDNA, and $1 \mu \mathrm{L}$ of each primer $(10 \mu \mathrm{M})$. Cycling conditions for all standards were described as above followed with dissociation curve analysis. Standard curves were generated as linear regression between $\mathrm{Ct}$ and $\log 10$ starting copy number of standard DNA. The Ct values were reported by the MX3000P MXPro program (Agilent Technologies, Palo Alto, USA). Amplification efficiency, slopes, and correlation coefficient $\left(R^{2}\right)$ were automatically calculated by the program.

To study the gene expression profiles during the four life stages, absolute quantitative PCR (AQ-PCR) was conducted to estimate their starting copy numbers. Gene specific primers, qTdTPSF/R, and qTdTREF/R, were designed according to the full-length cDNAs and these are listed in Table 1. RT-PCR was performed to obtain gene targets in the following cycling condition: initial denaturation $3 \mathrm{~min}$ at $95^{\circ} \mathrm{C}$ followed by 40 cycles including $5 \mathrm{~s}$ at $95^{\circ} \mathrm{C}, 10 \mathrm{~s}$ at $55^{\circ} \mathrm{C}, 15 \mathrm{~s}$ at $72{ }^{\circ} \mathrm{C}$. In the case of the T. dendrolimi samples, qPCR Ct values of TdTPS and TdTRE expression profiles were used to estimate starting copy numbers based on their standard curves.

\subsection{Enzyme Activity Measurements}

To obtain crude extracts for enzyme activity study, each sample $(0.0100 \pm 0.0002 \mathrm{~g}$ of larvae, pupae, prepupae, and adults) was homogenized at $0{ }^{\circ} \mathrm{C}$ (TGrinder OSE-Y20 Homogenizer, Tiangen, Beijing, China) after adding $2000 \mu \mathrm{L}$ of $20 \mathrm{mM}$ phosphate buffered saline (PBS, $\mathrm{pH}$ 5.8). The homogenates were centrifuged at $10,000 \times \mathrm{g}$ at $4{ }^{\circ} \mathrm{C}$ for $20 \mathrm{~min}(\mathrm{CP} 100 \mathrm{MX}$, Hitachi, Tokyo, Japan), and cuticle debris was removed. Supernatants in PBS were maintained at $-80^{\circ} \mathrm{C}$ to analyze TPS and TRE activity.

To determine TPS activity, the method of Dual et al. [54] was used. The qualitative analysis of trehalose was performed by thin layer chromatography (TLC); the quantitative analysis of trehalose 
synthase activity was investigated by examining the difference in glucose that was formed from the hydrolysis of maltose by TPS in the presence and absence of $\alpha$-glucosidase and measured by DNS. The reaction mixture, containing $150 \mu \mathrm{L}$ of crude extract and $100 \mu \mathrm{L}$ substrate (10\% maltose) was inactivated in a water bath at $60^{\circ} \mathrm{C}$ for $1 \mathrm{~h}$, and then in boiling water bath for $10 \mathrm{~min}$. After adding $85 \%$ phosphoric acid to adjust $\mathrm{pH}$ to $4.2,1 \mathrm{~mL}$ of diluted maltase (alpha-glucosidase) was added to the mixtures. The mixtures were inactivated in a water bath at $60{ }^{\circ} \mathrm{C}$ for $1 \mathrm{~h}$ and then in a boiling water bath for $10 \mathrm{~min}$. Diluting and volumetrizing the reaction solution, adding 1:2 (V reaction solution: V DNS method), boiling water bath for $10 \mathrm{~min}$, cooled in an ice bath, then the absorbance was measured at $550 \mathrm{~nm}$.

TRE activity was measured as described previously by the 3,5-dinitrosalicylic acid colorimetric method (DNS method) with absorbance measured at $540 \mathrm{~nm}[55,56]$. One unit (U) of enzyme activity was defined as the amount of enzyme capable of releasing $1 \mathrm{mg}$ of reducing sugar per minute. The reaction mixture consisted of $500 \mu \mathrm{L}$ crude extract and $500 \mu \mathrm{L}$ DNS solution. The reaction was stopped by heating in boiling water for $5 \mathrm{~min}$, then $4 \mathrm{~mL}$ of a pH $5.8 \mathrm{KH} 2 \mathrm{PO} 4-\mathrm{NAOH}$ buffer solution was added.

\subsection{Statistical Analyses}

Each treatment was performed using three biological and three technical replicates. Multifactor analysis (PROC GLM) of variance was conducted to evaluate temperatures and effect of developmental stage on the gene expression and enzyme activities of parasitoids using Tukey's test. The qualities of biological parameters were compared using one-way analysis of variance (ANOVA) and multiple comparisons of means were conducted using Tukey's test. Before analysis, percentage data were arcsine square root-transformed, and the data on the number of adults produced were $\log _{10}$-transformed to fit a normal distribution. For absolute quantification analysis, the number of molecules was expressed as the mean of the $\log _{10}$-converted value \pm standard error. In all experiments, differences among means were considered significant at $p<0.05$. Statistical analyses were conducted using SPSS 22.0 software (SPSS Inc., Chicago, IL, USA).

\section{Results}

\subsection{Cloning and Characterization of Full-Length TdTPS and TdTRE cDNAs}

To identify the TdTPS and TdTRE, cDNA fragments involved in trehalose metabolism were identified through T. dendrolimi transcriptome data (Hiseq 2000, Illumina, Santiago, USA). Based on the cDNA fragments, specific primers were performed and full-length cDNA of TdTPS and TdTRE was obtained by RACE-PCR. The full length TdTPS gene has $3189 \mathrm{bp}$, and the cDNA has a $2358 \mathrm{bp}$ open reading frame (ORF), encoding a polypeptide of 785 amino acids with an estimated molecular weight of approximately $88.60 \mathrm{kDa}$ and a pI of 6.56. The ORF was identical to the homolog from Trichogramma pretiosum (100\%) (Table 2 ). Sequence analysis showed that the deduced amino acid sequence includes a conserved TPS domain (aa 1-478, E $=1 \times 10^{-133}$ ) and a TPP domain (aa 515-739, E = $7 \times 10^{-34}$ ). Multiple protein alignment indicated that the TdTPS protein contains six conserved motifs (Figure 1). In addition to these specific motifs, TdTPS proteins contain the highly conserved domains, HDYHLML and DGMNLV, the same as TPS genes previously reported, such as in D. melanogaster, Catantops pinguis, and Delia antiqua [20,34,41]. Phylogenetic analysis showed that the TdTPS was more closely related to those of other Hymenoptera species (T. pretiosum, Nasonia vitripennis, and Copidosoma floridanum), and could be assigned to the same subgroup (Figure 2). The cloned TPS gene was designated as TdTPS and deposited into GenBank (MT108781). 

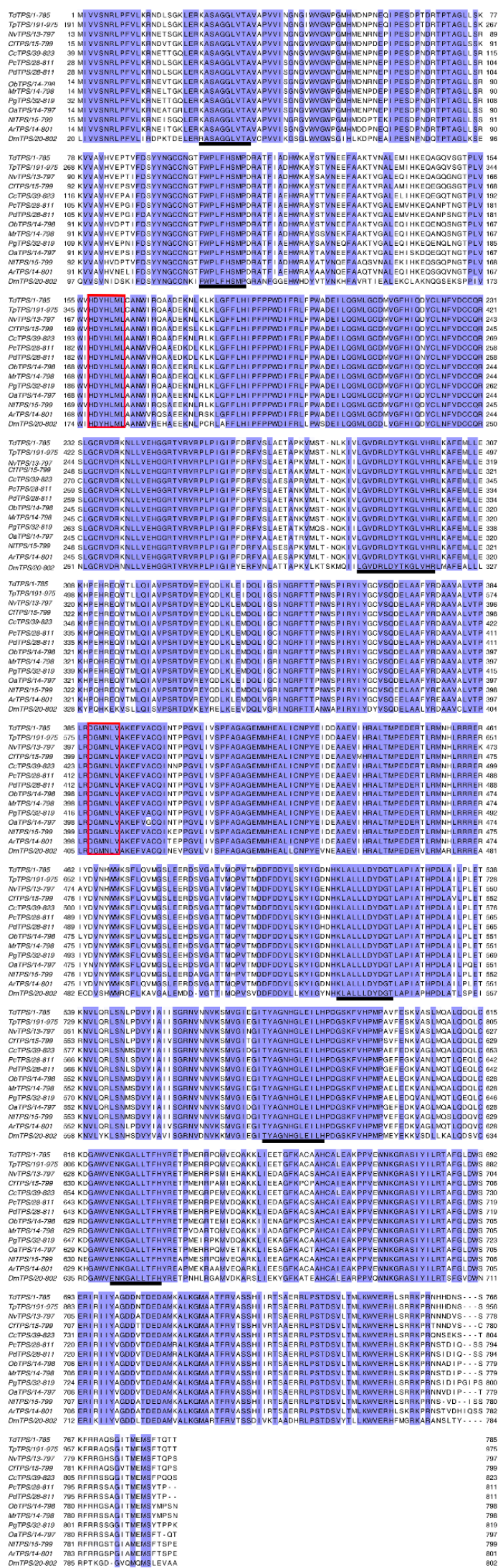

Figure 1. Alignment of TdTPS. Multiple alignment of trehalose-6-phosphate synthase (TPS) protein sequences from different insect species. Identical amino acid residues are shown in purple. The conserved motifs and the signatures are underlined and boxed, respectively. 
Table 2. The identities of TdTPS and TdTRE genes from different insects with T. dendrolimi.

\begin{tabular}{|c|c|c|c|}
\hline Genes & Insects & GenBank Number & Identity \\
\hline \multirow{12}{*}{ TdTPS } & Trichogramma pretiosum & XP_014221069 & $100 \%$ \\
\hline & Nasonia vitripennis & XP_016837588 & $94.78 \%$ \\
\hline & Copidosoma floridanum & XP_014213166 & $93.89 \%$ \\
\hline & Cephus cinctus & XP_015588847 & $92.87 \%$ \\
\hline & Osmia bicornis & XP_029055554 & $92.45 \%$, \\
\hline & Megachile rotundata & XP_003702415 & $92.32 \%$ \\
\hline & Polistes canadensis & XP_014609582 & $92.21 \%$ \\
\hline & Polistes dominula & XP_015172546 & $92.08 \%$ \\
\hline & Orussus abietinus & XP_012281922 & $91.96 \%$ \\
\hline & Pseudomyrmex gracilis & XP_020289281 & $91.85 \%$ \\
\hline & Neodiprion lecontei & XP_015522281 & $91.30 \%$ \\
\hline & Athalia rosae & XP_012252443 & $90.83 \%$ \\
\hline \multirow{10}{*}{ TdTRE } & Trichogramma pretiosum & XP_014236786 & $97.61 \%$ \\
\hline & Trichomalopsis sarcophagae & OXU30694 & $67.52 \%$ \\
\hline & Ceratosolen solmsi marchali & XP_011497766 & $67.18 \%$ \\
\hline & Nasonia vitripennis & XP_008215783 & $65.94 \%$ \\
\hline & Copidosoma floridanum & XP_014216724 & $60.41 \%$ \\
\hline & Harpegnathos saltator & XP_011144292 & $57.38 \%$ \\
\hline & Solenopsis invicta & XP_011170317 & $56.69 \%$ \\
\hline & Monomorium pharaonic & XP_028048276 & $56.42 \%$ \\
\hline & Pseudomyrmex gracilis & XP_020280302 & $56.31 \%$ \\
\hline & Orussus abietinus & XP_012271873 & $55.95 \%$ \\
\hline
\end{tabular}

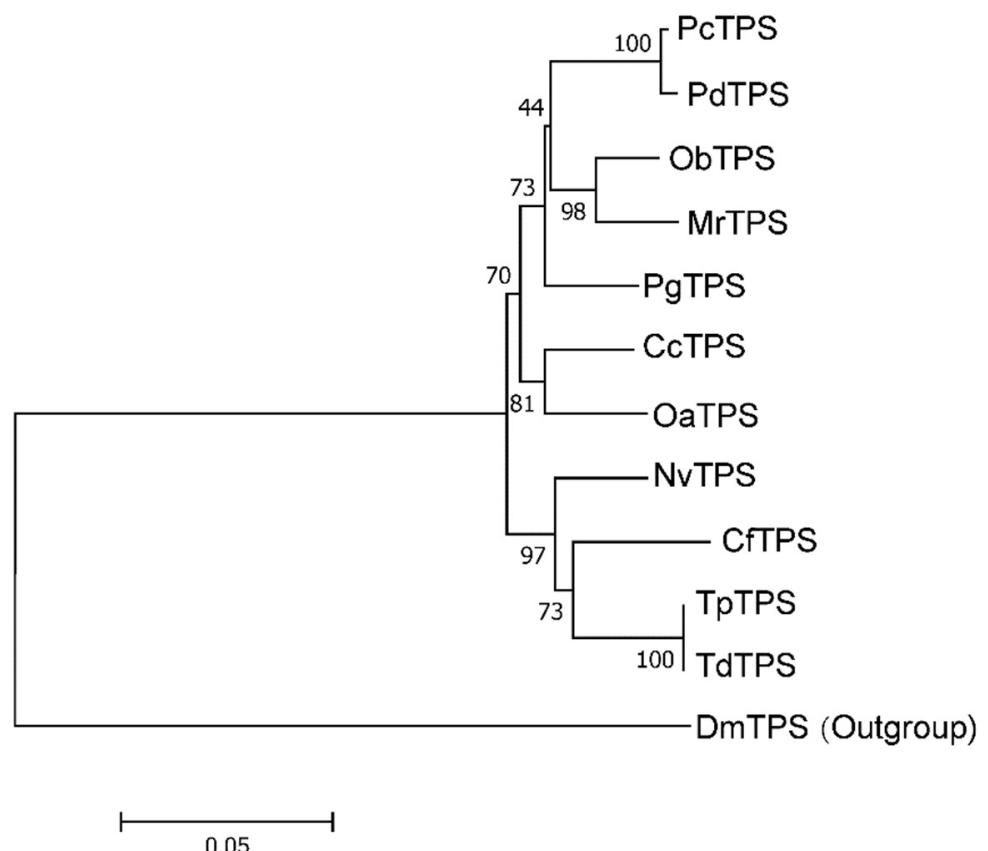

Figure 2. Phylogenetics of TdTPS. Phylogenetic tree constructed using the neighbor-joining (NJ) method. Percentage bootstrap values larger than 40 are shown on each branch. PcTPS: Polistes canadensis, XP_014609582; PdTPS: Polistes dominula, XP_015172546; ObTPS: Osmia bicornis, XP_029055554; MrTPS: Megachile rotundata, XP_003702415; PgTPS: Pseudomyrmex gracilis, XP_020289281; CcTPS: Cephus cinctus, XP_015588847; OaTPS: Orussus abietinus, XP_012281922; NvTPS: Nasonia vitripennis, XP_016837588; CfTPS: Copidosoma floridanum, XP_014213166; TpTPS: Trichogramma pretiosum, XP_014221069; DmTPS: Drosophila melanogaster, ABH06641.1.

The full length TdTRE cDNA consisted of $2228 \mathrm{bp}$, including an $1878 \mathrm{bp}$ open reading frame, encoding 625 amino acids with a predicted molecular weight of $73.2 \mathrm{kDa}$ and a pI of 6.40 . Basic 
Local Alignment Search Tool (BLAST) analysis revealed that TdTRE is 55.95-97.61\% identical in structure to other known insect TRE forms. TdTRE is also most similar to the TRE from T. pretiosum (97.61\%) (Table 2). The deduced amino acid sequence of TdTRE contains one conserved motif (YYLMRSQPPLLIPM) and a signal peptide sequence (Figure 3). Moreover, TdTRE had the same signature motifs, PGGRFREFYYWDSY and QWDYPNAWPP. For phylogenetic analysis, TdTRE was clustered with T. pretiosum TRE (Figure 4). Based on the sequence identity with known soluble form trehalase genes, TdTRE was identified as a soluble trehalase and deposited into GenBank (MT108782).

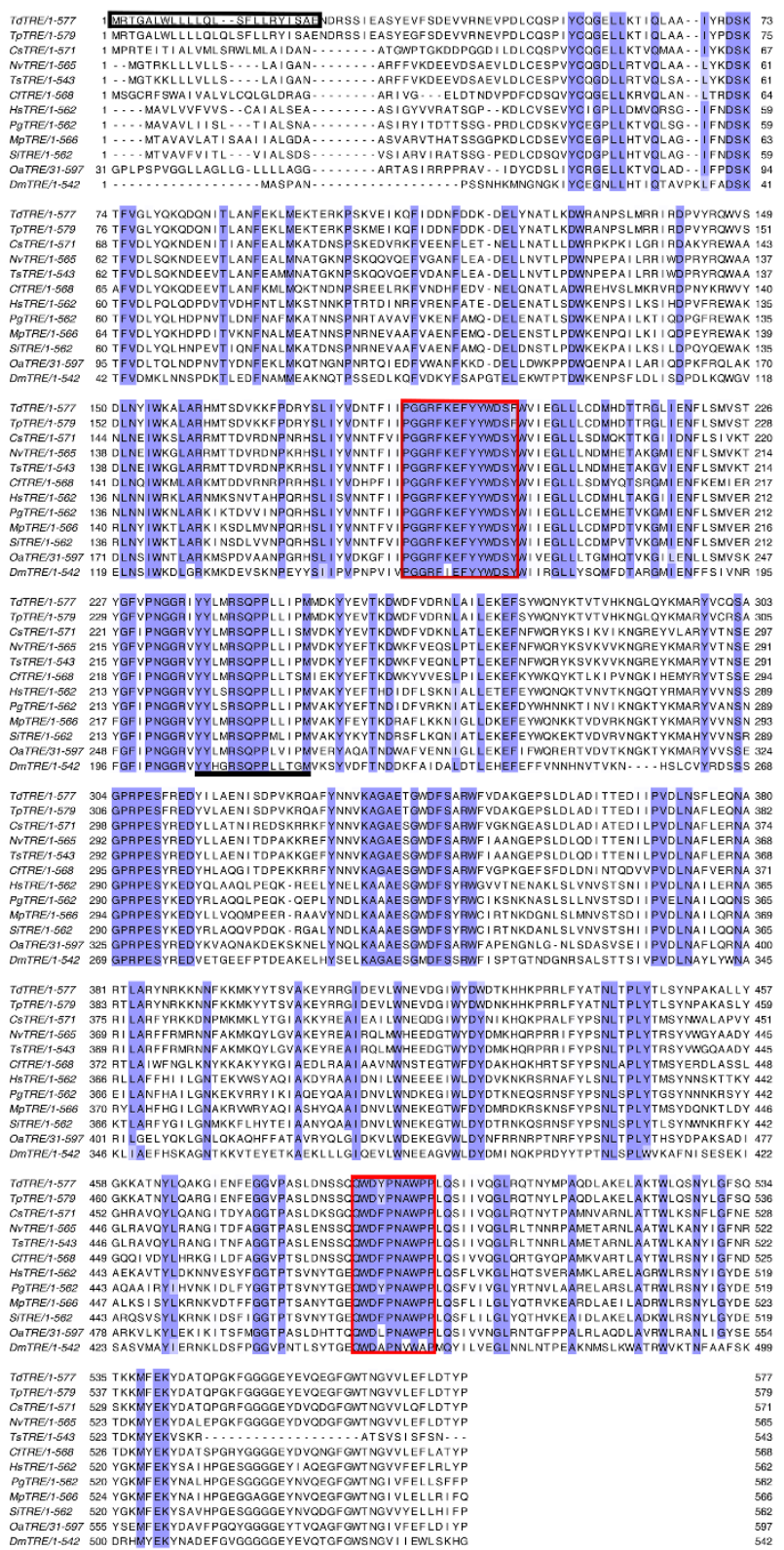

Figure 3. Alignment of TdTRE. Multiple alignment of soluble trehalase (TRE) protein sequences from different insect species. Identical amino acid residues are shown in purple. The conserved motifs, the signatures, and signal peptide sequence are underlined, red boxed, and black boxed, respectively. 


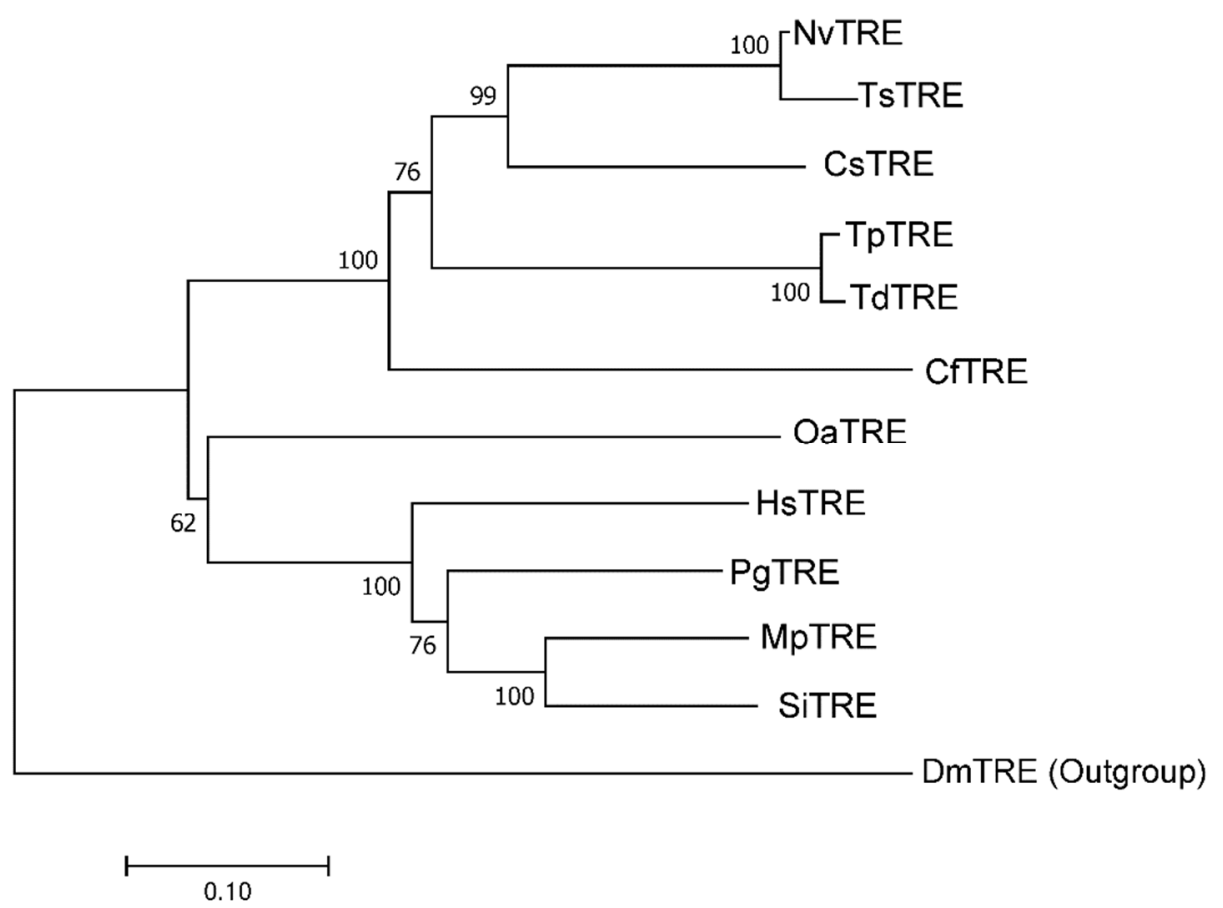

Figure 4. Phylogenetics of TdTRE. Phylogenetic tree constructed using the neighbor-joining (NJ) method. Percentage bootstrap values larger than 40 are shown on each branch. NvTRE: Nasonia vitripennis, XP_008215783; TsTRE: Trichomalopsis sarcophagae, OXU30694; CsTRE: Ceratosolen solmsi marchali, XP_011497766; TpTRE: Trichogramma pretiosum, XP_014236786; CfTRE: Copidosoma floridanum, XP_014216724; OaTRE: Orussus abietinus, XP_012271873; HsTRE: Harpegnathos saltator, XP_011144292; PgTRE: Pseudomyrmex gracilis, XP_020280302; MpTRE: Monomorium pharaonis, XP_028048276; SiTRE: Solenopsis invicta, XP_011170317; DmTRE: Drosophila melanogaster, NP_726025.1.

\subsection{Standard Curve}

Absolute quantification determines the actual copy numbers of target genes (TdTPS and TdTRE) by relating the $\mathrm{Ct}$ value to a standard curve and amplifying serial dilutions of plasmid standards by qPCR. The Ct values were measured and plotted against known copy numbers of the standard sample. The reaction efficiency and linearity for the serially diluted standards were of good quality for both genes (Figure 5). The standard curve covered a linear range of seven orders of magnitude. The slope $(-3.3550$ and -3.3396$)$ and the correlation coefficient $\left(R^{2}=0.9992\right.$ and 0.9990$)$ of the standard curve indicated that this assay could be used to quantify target RNA in T. dendrolimi. 


\section{a}

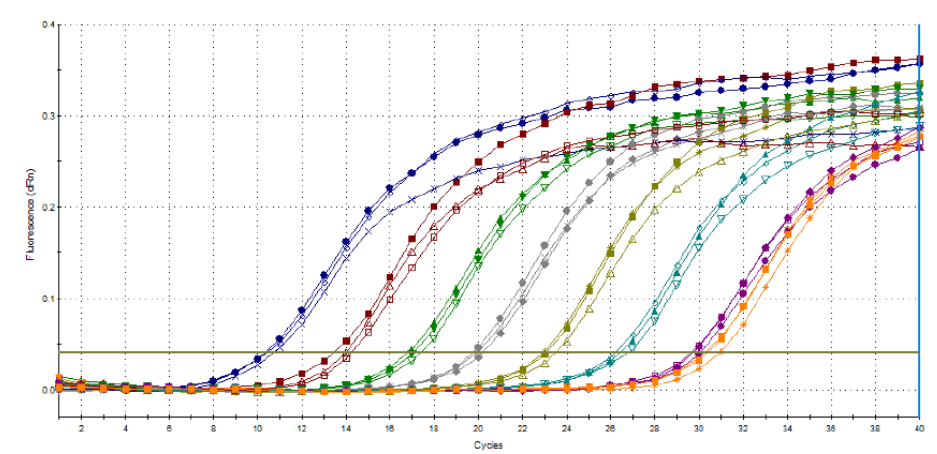

TdTPS

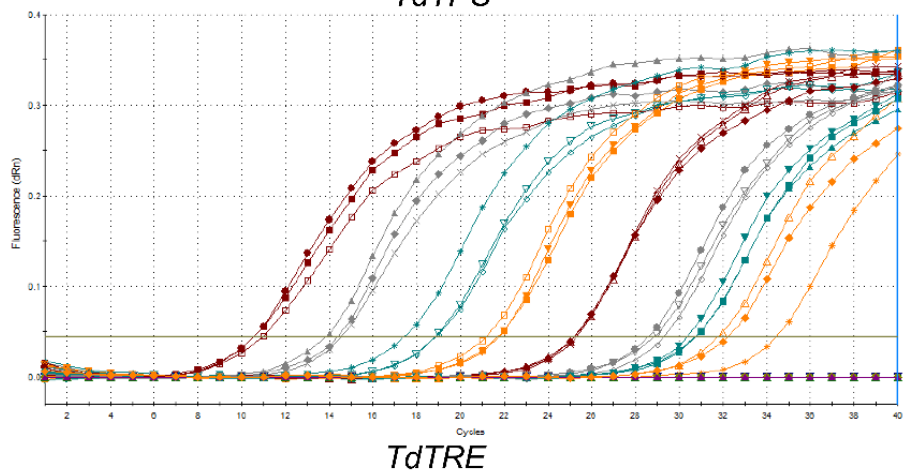

TdTRE

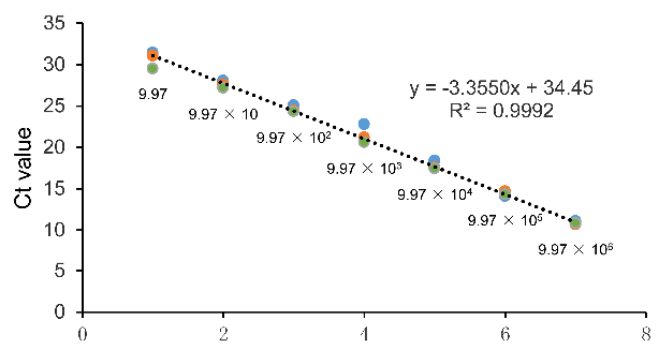

b

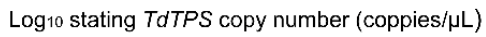

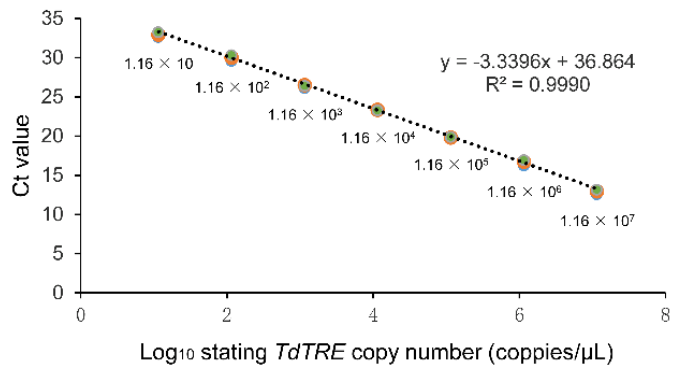

Figure 5. Standard curve for RT-qPCR amplification of standard sample. (a) Amplification plots for TdTPS and TdTRE; (b) standard curves of real-time PCR of TdTPS and TdTRE, using the method of absolute quantitative analysis, showing the testing in triplicate of a 10-fold dilution series containing a standard sample ranging from $9.97 \times 10^{6}$ to 9.97 and $1.16 \times 10^{7}$ to $1.16 \times 10^{1}$ copies per.

\subsection{Effect of Temperature on the Expression of TdTPS and TdTRE during Development}

Absolute quantification PCR (AQ-PCR) experiments to measure TdTPS and TdTRE absolute expression in four developmental stages at different temperatures revealed that there was interaction between two factors on the mRNA levels of the genes (Table 3). Table 4 shows that the levels of the two genes were more highly expressed at the optimum storage temperature $\left(13^{\circ} \mathrm{C}\right)$ in all developmental stages compared to the expression at the other treatment temperatures. The TdTRE transcripts were highly expressed at $16^{\circ} \mathrm{C}$. In contrast, at the optimum development temperature $\left(27^{\circ} \mathrm{C}\right)$, the expression 
levels of TdTPS and TdTRE were low in all developmental stages. TdTPS was highly expressed in prepupae when T. dendrolimi developed at the three treatment temperatures, and TdTPS expression level was also higher in adults when they developed at $16^{\circ} \mathrm{C}$. For trehalase, the absolute expression levels of TdTRE were very low in the larval stage at all temperatures, and much higher in the prepupal stage at $27^{\circ} \mathrm{C}$ and $16^{\circ} \mathrm{C}$.

Table 3. Multifactor variance analysis of effects of two factors on gene absolute expression and enzymes activity of Trichogramma dendrolimi reared on artificial medium.

\begin{tabular}{ccccc}
\hline Parameters & Factors & df & $\boldsymbol{F}$ & $\boldsymbol{p}$ \\
\hline Absolute & $\mathrm{A}$ & 2 & 2348.95 & $<0.001$ \\
expression of & $\mathrm{B}$ & 3 & 107.13 & $<0.001$ \\
TdTPS & $\mathrm{A} \times \mathrm{B}$ & 6 & 29.89 & $<0.001$ \\
\hline Absolute & $\mathrm{A}$ & 2 & 462.30 & $<0.001$ \\
expression of & $\mathrm{B}$ & 3 & 337.41 & $<0.001$ \\
TdTRE & $\mathrm{A} \times \mathrm{B}$ & 6 & 8.25 & $<0.001$ \\
\hline & $\mathrm{A}$ & 2 & 25.24 & $<0.001$ \\
Activity of TdTPS & $\mathrm{B}$ & 3 & 18.12 & $<0.001$ \\
& $\mathrm{~A} \times \mathrm{B}$ & 6 & 1.41 & 0.252 \\
\hline & $\mathrm{A}$ & 2 & 7.10 & $<0.001$ \\
Activity of TdTRE & $\mathrm{B}$ & 3 & 39.86 & $<0.001$ \\
& $\mathrm{~A} \times \mathrm{B}$ & 6 & 46.64 & $<0.001$ \\
\hline
\end{tabular}

A, temperature; B, developmental stage.

Table 4. The gene expression of TATPS and TdTRE of in vitro-reared Trichogramma dendrolimi reared at different temperatures and developmental stages.

\begin{tabular}{ccccc}
\hline \multirow{2}{*}{ Gene } & Developmental Stage & \multicolumn{2}{c}{ Gene Absolute Expression (Copy Number (Coppies/ $\boldsymbol{\mu L})$ ) } \\
\cline { 2 - 5 } & & $\mathbf{1 3}{ }^{\circ} \mathbf{C}$ & $\mathbf{1 6}{ }^{\circ} \mathbf{C}$ & $\mathbf{2 7}^{\circ} \mathbf{C}$ \\
\hline \multirow{2}{*}{ TdTPS } & Larva & $46175.06 \pm 6494.615 \mathrm{~A} \mathrm{c}$ & $1419.43 \pm 109.256 \mathrm{~B} \mathrm{~b}$ & $1082.30 \pm 53.480 \mathrm{~B} \mathrm{~b}$ \\
& Prepupa & $221227.25 \pm 8108.441 \mathrm{~A} \mathrm{a}$ & $9516.15 \pm 473.110 \mathrm{~B} \mathrm{a}$ & $1809.35 \pm 72.933 \mathrm{~B} \mathrm{a}$ \\
& Pupa & $84851.80 \pm 5186.980 \mathrm{~A} \mathrm{~b}$ & $4581.10 \pm 1153.243 \mathrm{~B} \mathrm{~b}$ & $859.34 \pm 20.148 \mathrm{~B} \mathrm{bc}$ \\
& Adult & $66806.48 \pm 1349.493 \mathrm{~A} \mathrm{bc}$ & $9716.46 \pm 799.299 \mathrm{~B} \mathrm{a}$ & $774.88 \pm 37.565 \mathrm{C} \mathrm{c}$ \\
\hline \multirow{2}{*}{ TdTRE } & Larva & $8.36 \pm 0.933 \mathrm{~A} \mathrm{c}$ & $9.72 \pm 0.758 \mathrm{~A} \mathrm{~b}$ & $2.41 \pm 0.566 \mathrm{~B} \mathrm{C}$ \\
& Prepupa & $126.08 \pm 7.207 \mathrm{~A} \mathrm{~b}$ & $158.51 \pm 10.949 \mathrm{~A} \mathrm{a}$ & $17.78 \pm 1.506 \mathrm{~B} \mathrm{a}$ \\
& Pupa & $122.12 \pm 4.192 \mathrm{~A} \mathrm{~b}$ & $136.25 \pm 7.018 \mathrm{~A} \mathrm{a}$ & $11.48 \pm 2.241 \mathrm{~B} \mathrm{ab}$ \\
& Adult & $162.04 \pm 12.807 \mathrm{~A} \mathrm{a}$ & $129.57 \pm 3.250 \mathrm{~A} \mathrm{a}$ & $11.19 \pm 0.886 \mathrm{~B} \mathrm{~b}$ \\
\hline
\end{tabular}

Mean \pm SE were calculated from three replicates. Mean \pm SE followed by the same capital letter within a row were not significantly different (Tukey's test: $p>0.05$ ); Mean \pm SE followed by the same lowercase letter within a column were not significantly different (Tukey's test: $p>0.05$ ).

\subsection{Changes in Enzyme Activities}

TdTPS and TdTRE enzyme activities were compared at different temperatures and different developmental stages, respectively. Comparison among temperatures indicated that TdTPS activities were similar at normal and cold temperatures. In larval and adult stages, TdTRE showed much higher activities at $16^{\circ} \mathrm{C}$ and $13{ }^{\circ} \mathrm{C}$. However, the TdTRE activity in prepupae showed the opposite result. In the pupal stage, TdTRE activities were similar at the three temperatures (Tables 3 and 5).

At $27^{\circ} \mathrm{C}$, TdTPS activity in the developmental stages was similar. TdTRE had significantly higher activity in the prepupal and pupal stages and then declined in the adult stage. The enzyme activity of TdTPS and TdTRE had a similar trend at $16^{\circ} \mathrm{C}$ and $13{ }^{\circ} \mathrm{C}$ in all T. dendrolimi developmental stages. Enzyme activities of TdTRE in prepupae declined sharply when they developed at $13^{\circ} \mathrm{C}$ and $16^{\circ} \mathrm{C}$. 
Table 5. Activity of the enzymes involved in trehalose metabolism of in vitro-reared Trichogramma dendrolimi reared at different temperatures and developmental stages.

\begin{tabular}{ccccc}
\hline \multirow{2}{*}{ Enzymes } & Developmental Stage & \multicolumn{3}{c}{ Activity $[\mu \mathrm{g} / \mathbf{m L}$ (Extract/min) $]$} \\
\cline { 3 - 5 } & & $\mathbf{1 3}{ }^{\circ} \mathbf{C}$ & $\mathbf{1 6}{ }^{\circ} \mathbf{C}$ & $\mathbf{2 7}{ }^{\circ} \mathbf{C}$ \\
\hline \multirow{3}{*}{ TdTPS } & Larva & $0.15 \pm 0.009 \mathrm{~A} \mathrm{ab}$ & $0.14 \pm 0.012 \mathrm{~A} \mathrm{~b}$ & $0.09 \pm 0.014 \mathrm{~A} \mathrm{a}$ \\
& Prepupa & $0.12 \pm 0.005 \mathrm{~A} \mathrm{~b}$ & $0.11 \pm 0.009 \mathrm{~A} \mathrm{~b}$ & $0.08 \pm 0.021 \mathrm{~A} \mathrm{a}$ \\
& Pupa & $0.12 \pm 0.015 \mathrm{~A} \mathrm{~b}$ & $0.11 \pm 0.006 \mathrm{~A} \mathrm{~b}$ & $0.09 \pm 0.006 \mathrm{~A} \mathrm{a}$ \\
\multirow{3}{*}{ TdTRE } & Adult & $0.20 \pm 0.014 \mathrm{~A} \mathrm{a}$ & $0.19 \pm 0.008 \mathrm{~A} \mathrm{a}$ & $0.11 \pm 0.010 \mathrm{~B} \mathrm{a}$ \\
& Larva & $0.52 \pm 0.032 \mathrm{~A} \mathrm{a}$ & $0.44 \pm 0.028 \mathrm{~A} \mathrm{a}$ & $0.28 \pm 0.022 \mathrm{~B} \mathrm{~b}$ \\
& Prepupa & $0.22 \pm 0.032 \mathrm{~B} \mathrm{~b}$ & $0.18 \pm 0.016 \mathrm{~B} \mathrm{~b}$ & $0.49 \pm 0.021 \mathrm{~A} \mathrm{a}$ \\
& Pupa & $0.47 \pm 0.019 \mathrm{~A} \mathrm{a}$ & $0.50 \pm 0.031 \mathrm{~A} \mathrm{a}$ & $0.50 \pm 0.012 \mathrm{~A} \mathrm{a}$ \\
& Adult & $0.50 \pm 0.013 \mathrm{~A} \mathrm{a}$ & $0.50 \pm 0.002 \mathrm{~A} \mathrm{a}$ & $0.22 \pm 0.012 \mathrm{~B} \mathrm{~b}$ \\
\hline
\end{tabular}

Mean \pm SE were calculated from three replicates. Mean \pm SE followed by the same capital letter within a row were not significantly different (Tukey's test: $p>0.05$ ); Mean \pm SE followed by the same lowercase letter within a column were not significantly different (Tukey's test: $p>0.05$ ).

\subsection{In Vitro Rearing at Different Temperatures}

The developmental durations and biological parameters at the five temperatures are shown in Table 6. The development of $\mathrm{T}$. dendrolimi at $13{ }^{\circ} \mathrm{C}, 16{ }^{\circ} \mathrm{C}, 20^{\circ} \mathrm{C}$, and $23^{\circ} \mathrm{C}$ prolonged for 21 days, 17 days, 8 days, and 5 days, respectively compared with those reared at the optimum temperature $\left(27^{\circ} \mathrm{C}\right)$. There were no significant differences in pupation rate, emergence rate, female proportion and number of normal adults among $16{ }^{\circ} \mathrm{C}, 20^{\circ} \mathrm{C}, 23{ }^{\circ} \mathrm{C}$, and $27{ }^{\circ} \mathrm{C}\left(F_{4,14}=4.070,135.396,2.430\right.$, and $64.434, p=0.033,0.000,0.116$ and 0.000 , respectively). The biological parameters (except female proportion) of $T$. dendrolimi reared on artificial medium were significantly affected by temperature. These parameters at $13{ }^{\circ} \mathrm{C}$ was lowest compared to that of other test temperatures.

Table 6. Developmental quality of in vitro reared T. dendrolimi at different temperatures.

\begin{tabular}{cccccccccc}
\hline & \multicolumn{4}{c}{ Developmental Duration (D) } & \multicolumn{3}{c}{ Biological Parameters } \\
\cline { 2 - 9 } Temperature & Egg & Larva & Prepupa & Pupa & $\begin{array}{c}\text { Total } \\
\text { Duration }\end{array}$ & Pupation Rate (\%) & $\begin{array}{c}\text { Emergence } \\
\text { Rate (\%) }\end{array}$ & $\begin{array}{c}\text { Female } \\
\text { Proportion (\%) }\end{array}$ & $\begin{array}{c}\text { Number of } \\
\text { Normal Adults }\end{array}$ \\
\hline $27^{\circ} \mathrm{C}$ & 2 & 2 & 2 & 4 & 10 & $96.77 \pm 0.391 \mathrm{a}$ & $77.44 \pm 1.451 \mathrm{a}$ & $88.16 \pm 0.555 \mathrm{a}$ & $876.00 \pm 48.03 \mathrm{a}$ \\
$23^{\circ} \mathrm{C}$ & 3 & 3 & 2 & 5 & 13 & $96.44 \pm 0.441 \mathrm{ab}$ & $75.16 \pm 1.326 \mathrm{a}$ & $87.50 \pm 0.620 \mathrm{a}$ & $805.33 \pm 35.044 \mathrm{a}$ \\
$20^{\circ} \mathrm{C}$ & 4 & 4 & 3 & 7 & 18 & $96.48 \pm 0.395 \mathrm{ab}$ & $76.59 \pm 0.728 \mathrm{a}$ & $87.62 \pm 0.949 \mathrm{a}$ & $814.67 \pm 13.119 \mathrm{a}$ \\
$16^{\circ} \mathrm{C}$ & 5 & 9 & 4 & 9 & 27 & $94.88 \pm 1.35 \mathrm{ab}$ & $75.86 \pm 2.499 \mathrm{a}$ & $88.00 \pm 0.392 \mathrm{a}$ & $904.00 \pm 72.746 \mathrm{a}$ \\
$13^{\circ} \mathrm{C}$ & 6 & 9 & 7 & 9 & 31 & $92.81 \pm 1.041 \mathrm{~b}$ & $36.03 \pm 1.159 \mathrm{~b}$ & $85.55 \pm 0.724 \mathrm{a}$ & $92.67 \pm 5.897 \mathrm{~b}$ \\
\hline
\end{tabular}

Mean \pm SE values were calculated from three replicates. Mean \pm SE followed by the same lower case letter within a column are not significantly different (Tukey's test: $p<0.05$ ).

\section{Discussion}

In this study, only the TPS gene of T. dendrolimi was obtained. The deduced amino acid sequence reveals that TdTPS, similar to the DaTPS gene in Delia antiqua [20], has two conserved functional domains that include an N-terminal TPS domain and a C-terminal TPP domain [43]. This result supports the conclusion that the insect TPS is a fused gene [57]. There are two signature motifs (HDYHL and DGMNLV) of TPS protein sequences for insects, plants, bacteria, fungi, and nematodes. Multiple protein alignment results show that, besides the signature motifs, TdTPS has other conserved motifs. Two types of trehalase exist in insects, a soluble trehalase and a membrane-bound trehalase with a transmembrane domain near the C-terminus $[2,29,44,58,59]$. Based on the conserved motif and specific signatures in deduced amino acid sequences, we identified the existence of the soluble form of trehalase (TdTRE) in in vitro reared T. dendrolimi.

Trehalose occurs in all insect species and is the most characteristic sugar in the insect hemolymph [57]. However, it has not been detected in the developmental stages of some species [2,23]. In the present study, TdTPS and TdTRE were expressed in larval, prepupal, pupal, and adult stages, whether they developed at the optimum development temperature or at sustained low temperatures. 
The results suggest that sustained low temperature has a strong effect on the expression level of trehalase genes in $T$. dendrolimi, which may facilitate the utilization of trehalose. A comparison of the expression levels of TdTPS and TdTRE at the tested temperature showed that sustained low temperature can upregulate their expression, but the expression of TdTRE was much lower than TdTPS. These indicated that the anabolism of trehalose was greater than its catabolism during low temperature development. Meanwhile, the reduction of trehalase activity inhibits the trehalose catabolism, which indirectly helps the trehalose accumulation. TdTPS might play a more important role than TdTRE in cold induction.

Prepupal stage is a critical developmental period for Trichogramma. The nutrient (host egg liquid) has been consumed by the end of larval stage and digestion of this food allows for the accumulation of energy used by the following pupal and adult stages. There were studies that have reported that the prepupa is the best stage for short-term storage of Trichogramma spp. reared in vivo [12]. In a previous study, sustained temperatures at $13{ }^{\circ} \mathrm{C}$ for 4 weeks was the optimum short-term storage condition for prepupae of in vitro reared T. dendrolimi [12]. Here, we explain the results of the previous study in terms of molecular physiology. TdTPS had a higher expression level in prepupae at the three test temperatures. Meanwhile, TdTPS had a high expression level in all stages when T. dendrolimi developed at low temperatures, especially at $13^{\circ} \mathrm{C}$. The enzymatic activity of TdTPS showed a similar change during the entire development. With a decrease of temperature, the activity increased. TdTRE showed a high expression level, but the enzymatic activity decreased at low temperatures in the prepupal stage. This trend was opposite to that observed at $27^{\circ} \mathrm{C}$. These findings indicate that the gene regulation for TdTRE, the soluble trehalase, might not determine the enzyme activity directly. However, there is no evidence to prove whether other soluble trehalase or membrane-bound trehalase genes exist in T. dendrolimi yet. Large-scale expression of TPS by insects before pupation promotes the synthesis of trehalose, leading to a high level of trehalose in the pupa stage. Under sustained low temperature, trehalase activity was inhibited in the prepupae since trehalose accumulation was probably required during this period to meet the energy required for chitin synthesis in the pupa and for adult emergence, suggesting its potential role in molting from pre-pupae to pupae. However, TdTRE is more active than TdTPS during cold stress. In vitro reared T. dendrolimi does not diapause under sustained low temperature stress, but cold only prolongs the development period after which development proceeds normally. In addition, the trehalose supplemented in artificial medium [9] needs to be consumed. On the other hand, in vitro reared T. dendrolimi could complete development above $13{ }^{\circ} \mathrm{C}$ because the trehalose added to the artificial medium may improve its cold tolerance. This protected the parasitoids, especially the young larvae, from low temperature injury. Trehalose was synthesized and accumulated at the same time for metabolism and utilization during the period. This indicates that trehalose might regulate growth of in vitro reared $T$. dendrolimi and the metabolic process of cold tolerance.

Trehalose concentration in insect blood hemolymph is not under homeostatic regulation. It is based on environmental conditions, physiological state, and nutrition. Trichogramma complete their development in the host egg before adult emergence. During development, the accumulation of trehalose helps the insects to resist environmental temperature stress and the stress of host malnutrition. A comparison of the trehalose contents and trehalase activity of T. dendrolimi produced in vitro and in vivo showed that the adults produced in vitro had higher trehalose content and trehalase activity over 10 generations [11]. Therefore, the responses and resistance of egg parasitoids to environmental stress may be different from those of other insects.

Future work will need to focus on the effects of different hosts (nutrition) on trehalose metabolism in T. dendrolimi, and determine how the trehalase genes are regulated under stress conditions.

\section{Conclusions}

Trehalose synthetase and soluble trehalase genes were identified from T. dendrolimi reared on an artificial medium. Sustained low temperature stress had different effects on trehalose metabolism related enzyme genes and enzyme activities of Trichogramma. The anabolism and catabolism of 
trehalose maintained a dynamic balance in the process of metabolism. Trehalose indeed accumulated as an energy source to be used in adverse conditions. TdTPS and TdTRE may be considered as an energy source and responsive enzymes for cold resistance in Trichogramma. The prepupa stage is a key period of Trichogramma development, in which the expression of genes involved in trehalose metabolism and corresponding enzyme activities undergo substantial changes. It' is found that $13{ }^{\circ} \mathrm{C}$ appears to be the cold tolerance threshold temperature for in vitro reared T. dendrolimi. Since it remains unknown whether or not the in vitro reared $T$. dendrolimi could diapause without negatively affecting their reproductive parameters, we suggest that in vitro reared $T$. dendrolimi could be reared at temperatures of $16{ }^{\circ} \mathrm{C}, 20{ }^{\circ} \mathrm{C}$, and $23{ }^{\circ} \mathrm{C}$ to reduce rearing costs.

Author Contributions: Conceptualization, X.L., J.L., and L.-y.L.; methodology, X.L.; formal analysis, X.L.; resources, S.-c.H. and Z.-g.L.; data curation, X.L.; writing-original draft preparation, X.L.; writing-review and editing, J.L., S.-c.H., and L.-y.L.; visualization, X.L. and Z.-g.L.; supervision, L.-y.L. and J.L.; project administration, X.L. and J.L.; funding acquisition, X.L., J.L., S.-c.H., and Z.-g.L. All authors have read and agreed to the published version of the manuscript.

Funding: This research was funded by the Key-Area Research and Development Program of Guangdong Province (grant no. 2020B020223004), GDAS Special Project of Science and Technology Development (grant nos. 2020GDASYL-20200301003, 2020GDASYL-20200104025, and 2018GDASCX-0107), National Natural Science Foundation of China (grant no. 31501702), Science \& Technology Planning Project of Guangdong (grant no. 2019B030316018).

Acknowledgments: We would like to thank Patrick De Clercq provided guidance; Chuan-bu Gao prepared the figures; Jun-gang Qian assisted with the experiment.

Conflicts of Interest: The authors declare no conflict of interest.

\section{References}

1. Rivero, A.; Casas, J. Incorporating physiology into parasitoid behavioral ecology: The allocation of nutritional resources. Res. Popul. Ecol. 1999, 41, 39-45. [CrossRef]

2. Thompson, S.N. Trehalose-The insect 'blood' sugar. Adv. Insect Physiol. 2003, 31, 203-285. [CrossRef]

3. Phillips, C.B.; Hiszczynska-Sawicka, E.; Iline, I.I.; Novoselov, M.; Jiao, J.; Richards, N.K.; Hardwick, S. A modified enzymatic method for measuring insect sugars and the effect of storing samples in ethanol on subsequent trehalose measurements. Biol. Control 2008, 126, 127-135. [CrossRef]

4. Zhang, J.J.; Ruan, C.C.; Zang, L.S.; Shao, X.W.; Shi, S.S. Technological improvements for mass production of Trichogramma and current status of their applications for biological control on agricultural pests in China. Chin. J. Biol. Control 2015, 31, 638-646. [CrossRef]

5. Zhang, J.J.; Zhang, X.; Zang, L.S.; Du, W.M.; Hou, Y.Y.; Ruan, C.C.; Desneux, N. Advantages of diapause in Trichogramma dendrolimi mass production via eggs of the Chinese silkworm, Antheraea Pernyi. Pest Manag. Sci. 2018, 74, 959-965. [CrossRef] [PubMed]

6. Cônsoli, F.L.; Grenier, S. In vitro Rearing of Egg Parasitoids. In Egg Parasitoids in Agroecosystems with Emphasis on Trichogramma; Cônsoli, F.L., Parra, J.R.P., Zucchi, R.A., Eds.; Springer: Berlin/Heidelberg, Germany, 2010; pp. 293-313.

7. Li, L.Y.; Han, S.C.; Lü, X. Mass rearing Trichogramma on Artificial Media in China. In Biological Control of Pests Using Trichogramma: Current Status and Perspectives; Vinson, S.B., Greenberg, S.M., Liu, T.X., Rao, A., Volosciuc, L.F., Eds.; Northwest A \& F University Press: Yangling, China, 2015; pp. 32-57.

8. Lü, X.; Han, S.C.; Li, L.Y.; Grenier, S.; De Clercq, P. The potential of trehalose to replace insect hemolymph in artificial media for Trichogramma dendrolimi Matsumura (Hymenoptera: Trichogrammatidae). Insect Sci. 2013, 20, 629-636. [CrossRef] [PubMed]

9. Lü, X.; Han, S.C.; De Clercq, P.; Dai, J.Q.; Li, L.Y. Orthogonal array design for optimization of an artificial medium for In vitro rearing of Trichogramma dendrolimi. Entomol. Exp. Appl. 2014, 152, 52-60. [CrossRef]

10. Lü, X.; Han, S.C.; Li, Z.G.; Li, L.Y. Biological characters of Trichogramma dendrolimi (Hymenoptera: Trichogrammatidae) reared in vitro versus in vivo for thirty generations. Sci. Rep. 2017, 7, 17928. [CrossRef]

11. Lü, X.; Han, S.-C.; Li, L.-Y. Biochemical analyses of Trichogramma dendrolimi (Hymenoptera: Trichogrammatidae) In vitro and in vivo rearing for 10 generations. Fla. Entomol. 2015, 98, 911-915. [CrossRef] 
12. Lü, X.; Han, S.C.; Li, J.; Liu, J.S.; Li, Z.G. Effects of cold storage on the quality of Trichogramma dendrolimi Matsumura (Hymenoptera: Trichogrammatidae) reared on artificial medium. Pest Manag. Sci. 2019, 75, 1328-1338. [CrossRef] [PubMed]

13. Li, L.Y.; Zhang, Y.H.; Zhang, R.H. Influence of temperature on the growth and development of Trichogramma spp. on interspecific and intraspecific levels. Nat. Enemies Insects 1983, 5, 1-5.

14. Shi, Z.H.; Liu, S.S. The influence of temperature and humidity on the population increase of Trichogramma dendrolimi. Acta Ecol. Sin. 1993, 13, 328-333.

15. Wang, C.L.; Wang, H.X.; Wang, Y.A.; Lu, H. Studies on the relationship of temperature and development of Trichogramma dendrolimi Matsumura. Zool. Res. 1981, 2, 317-326.

16. Li, L.J.; Lu, X.; Zhang, G.H.; Zhou, S.X.; Chang, X.; Ding, Y. Difference of development characters of two Trichogramma Species at various temperatures. J. Northeast Agr. Sci. 2017, 42, 23-26. [CrossRef]

17. Hayakawa, Y.; Chino, H. Temperature-dependent activation or inactivation of glycogen phosphorylase and synthase of fat body of the silkworm, Philosamia cynthia: The possible mechanism of the temperature-dependent interconversion between glycogen and trehalose. Insect Biochem. 1982, 12, 361-366. [CrossRef]

18. Khani, A.; Moharramipour, S.; Barzegar, M. Cold tolerance and trehalose accumulation in overwintering larvae of the codling moth, Cydia pomonella (Lepidoptera: Tortricidae). Eur. J. Entomol. 2007, 104, 385. [CrossRef]

19. Tang, B.; Qin, Z.; Shi, Z.K.; Wang, S.; Guo, X.J.; Wang, S.G.; Zhang, F. Trehalase in Harmonia axyridis (Coleoptera: Coccinellidae): Effects on beetle locomotory activity and the correlation with trehalose metabolism under starvation conditions. Appl. Entomol. Zool. 2014, 49, 255-264. [CrossRef]

20. Guo, Q.; Hao, Y.J.; Li, Y.; Zhang, Y.J.; Ren, S.; Si, F.L.; Chen, B. Gene cloning, characterization and expression and enzymatic activities related to trehalose metabolism during diapause of the onion maggot Delia antiqua (Diptera: Anthomyiidae). Gene 2015, 565, 106-115. [CrossRef]

21. Tang, B.; Wei, P.; Zhao, L.N.; Shi, Z.K.; Shen, Q.D.; Yang, M.M.; Xie, G.Q.; Wang, S.G. Knockdown of five trehalase genes using RNA interference regulates the gene expression of the chitin biosynthesis pathways in Tribolium castaneum. BMC Biotechnol. 2016, 16, 67. [CrossRef]

22. Wingler, A. The function of trehalose biosynthesis in plants. Phytochemistry 2002, 60, 437-440. [CrossRef]

23. Elbein, A.D.; Pan, Y.T.; Pastuszak, I.; Carroll, D. New insights on trehalose: A multifunctional molecule. Glycobiology 2003, 13, 17R-27R. [CrossRef]

24. Heimpel, G.E.; Rosenheim, J.A.; Kattari, D. Adult feeding and lifetime reproductive success in the parasitoid Aphytis melinus. Entomol. Exp. Appl. 1997, 83, 305-315. [CrossRef]

25. Olson, D.; Andow, D. Larval crowding and adult nutrition effects on longevity and fecundity of female Trichogramma nubilale Ertle \& Davis (Hymenoptera: Trichogrammatidae). Environ. Entomol. 1998, 27, 508-514. [CrossRef]

26. Wyatt, G.R. The biochemistry of sugars and polysaccharides in insects. Adv. Insect Physiol. 1967, 43, 287-360. [CrossRef]

27. Bale, J.; Hayward, S. Insect overwintering in a changing climate. J. Exp. Biol. 2010, 213, 980-994. [CrossRef]

28. Araj, S.E.; Wratten, S.; Lister, A.; Buckley, H.; Ghabeish, I. Searching behavior of an aphid parasitoid and its hyperparasitoid with and without floral nectar. Biol. Control 2011, 57, 79-84. [CrossRef]

29. Mitsumasu, K.; Azuma, M.; Niimi, T.; Yamashita, O.; Yaginuma, T. Membrane-penetrating trehalase from silkworm Bombyx mori: Molecular cloning and localization in larval midgut. Insect Mol. Biol. 2005, 14, 501-508. [CrossRef]

30. Santos, R.; Alves-Bezerra, M.; Rosas-Oliveira, R.; Majerowicz, D.; Meyer-Fernandes, J.R.; Gondim, K.C. Gene identification and enzymatic properties of a membrane bound trehalase from the ovary of Rhodnius prolixus. Arch. Insect Biochem. 2012, 81, 199-213. [CrossRef]

31. Shen, Q.D.; Yang, M.M.; Xie, G.Q.; Wang, H.J.; Zhang, L.; Qiu, L.Y.; Wang, S.G.; Tang, B. Excess trehalose and glucose affects chitin metabolism in brown planthopper (Nilaparvata lugens). J. Asia Pac. Entomol. 2017, 20, 449-455. [CrossRef]

32. Dindo, M.L.; Grenier, S. Production of Dipteran Parasitoids. In Mass Production of Beneficial Organisms: Invertebrates and Entomopathogens; Morales-Ramos, J.A., Guadalupe Rojas, M., Shapiro-Ilan, D.I., Eds.; Academic Press: London, UK, 2014; pp. 101-143. 
33. Dindo, M.L.; Stangolini, L.; Marchetti, E. A simplified artificial medium for the In vitro rearing of Exorista larvarum (Diptera: Tachinidae). Biocont. Sci. Tech. 2010, 20, 407-410. [CrossRef]

34. Chen, Q.; Ma, E.; Behar, K.L.; Xu, T.; Haddad, G.G. Role of trehalose phosphate synthase in anoxia tolerance and development in Drosophila melanogaster. J. Biol. Chem. 2002, 277, 3274-3279. [CrossRef] [PubMed]

35. Chung, J.S. A trehalose 6-phosphate synthase gene of the hemocytes of the blue crab, Callinectes sapidus: Cloning, the expression, its enzyme activity and relationship to hemolymph trehalose levels. Saline Syst. 2008, 4, 18. [CrossRef]

36. Campbell, J.A.; Davies, G.J.; Bulone, V.; Henrissat, B.V. A classification of nucleotide-diphospho-sugar glycosyltransferases based on amino acid sequence similarities. Biochem. J. 1997, 326, 929-939. [CrossRef]

37. Zhu, K.Y.; Merzendorfer, H.; Zhang, W.Q.; Zhang, J.Z.; Muthukrishnan, S. Biosynthesis, turnover, and functions of chitin in insects. Annu. Rev. Entomol. 2006, 61, 177-196. [CrossRef]

38. Qin, Z.; Wang, S.; Wei, P.; Xu, C.D.; Tang, B.; Zhang, F. Molecular cloning and expression in cold induction of trehalose-6-phosphate synthase gene in Harmonia axyridis (Pallas). Acta Entomol. Sin. 2012, 55, 651-658. [CrossRef]

39. Xu, J.; Bao, B.; Zhang, Z.F.; Yi, Y.Z.; Xu, W.H. Identification of a novel gene encoding the trehalose phosphate synthase in the cotton bollworm, Helicoverpa armigera. Glycobiology 2009, 19, 250-257. [CrossRef] [PubMed]

40. Tang, B.; Chen, J.; Yao, Q.; Pan, Z.Q.; Xu, W.H.; Wang, S.G.; Zhang, W.Q. Characterization of a trehalose-6-phosphate synthase gene from Spodoptera exigua and its function identification through RNA interference. J. Insect Physiol. 2010, 56, 813-821. [CrossRef]

41. Tang, B.; Zheng, H.Z.; Xu, Q.; Zou, Q.; Wang, G.J.; Zhang, F.; Wang, S.G.; Zhang, Z.H. Cloning and pattern of expression of trehalose-6-phosphate synthase cDNA from Catantops pinguis (Orthoptera: Catantopidae). Eur. J. Entomol. 2011, 108, 355-363. [CrossRef]

42. Kern, C.; Wolf, C.; Bender, F.; Berger, M.; Noack, S.; Schmalz, S.; Ilg, T. Trehalose-6-phosphate synthase from the cat flea Ctenocephalides felis and Drosophila melanogaster: Gene identification, cloning, heterologous functional expression and identification of inhibitors by high throughput screening. Insect Mol. Biol. 2012, 21, 456-471. [CrossRef]

43. Tang, B.; Chen, X.; Liu, Y.; Tian, H.; Liu, J.; Hu, J.; Xu, W.; Zhang, W. Characterization and expression patterns of a membrane-bound trehalase from Spodoptera exigua. BMC Mol. Biol. 2008, 9, 51. [CrossRef] [PubMed]

44. Tatun, N.; Singtripop, T.; Tungjitwitayakul, J.; Sakurai, S. Regulation of soluble and membrane-bound trehalase activity and expression of the enzyme in the larval midgut of the bamboo borer Omphisa fuscidentalis. Insect Biochem. Mol. Biol. 2008, 38, 788-795. [CrossRef]

45. Gu, J.; Shao, Y.; Zhang, C.; Liu, Z.; Zhang, Y. Characterization of putative soluble and membrane-bound trehalases in a hemipteran insect, Nilaparvata lugens. J. Insect Physiol. 2009, 55, 997-1002. [CrossRef]

46. Tang, B.; Wei, P.; Chen, J.; Wang, S.G.; Zhang, W.Q. Progress in gene features and functions of insect trehalases. Acta Entomol. Sin. 2012, 55, 1315-1321. [CrossRef]

47. Parkinson, N.M.; Conyers, C.M.; Keen, J.N.; MacNicoll, A.D.; Smith, I.; Weaver, R.J. cDNAs encoding large venom proteins from the parasitoid wasp Pimpla hypochondriaca identified by random sequence analysis. Comp. Biochem. Physiol. C Toxicol. Pharmacol. 2003, 134, 513-520. [CrossRef]

48. Kumar, S.; Stecher, G.; Tamura, K. MEGA7: Molecular Evolutionary Genetics Analysis Version 7.0 for bigger datasets. Mol. Biol. Evol. 2016, 33, 1870-1874. [CrossRef]

49. Higgins, D.G.; Bleasby, A.J.; Fuchs, R. CLUSTAL V: Improved software for multiple sequence alignment. Comput. Appl. Biosci. 1992, 8, 189-191. [CrossRef]

50. Julie, D.T.; Arnaud, M.; Andrew, W.; Jim, P.; Geoffrey, J.B.; Frédéric, P.; Olivier, P. MACSIMS: Multiple alignment of complete sequences information management system. BMC Bioinform. 2006, 2, 317-318. [CrossRef]

51. Naruya, S.; Masatoshi, N. The neighbor-joining method: A new method for reconstructing phylogenetic trees. Mol. Biol. Evol. 1987, 4, 406-425. [CrossRef]

52. Hou, Y.B.; Zhang, H.; Miranda, L.; Lin, S.J. Serious overestimation in quantitative PCR by circular (Supercoiled) plasmid standard: Microalgal pcna as the model gene. PLoS ONE 2010, 5, e9545. [CrossRef]

53. Godornes, C.; Leader, B.T.; Molini, B.J.; Centurion-Lara, A.; Lukehart, S.A. Quantitation of rabbit cytokine mRNA by Real-Time RT-PCR. Cytokine 2007, 38, 1-7. [CrossRef]

54. Duan, F.; Gao, Y.H.; Yuan, J.G. Research on activity measurement of trehalose synthase. Food Drug 2008, 10, 47-50. [CrossRef] 
55. Miller, G.L. Use of dinitrosalicylic acid reagent for determination of reducing sugar. Anal. Chem. 1959, $31,426$. [CrossRef]

56. Wang, N.S. Experiment no. 4A: Glucose Assay by Dinitrosalicylic Colorimetric Method. 2004. Available online: http://www.eng.umd.edu/ \{\}nsw/ench485/lab4a.htm (accessed on 27 January 2015).

57. Su, Z.H.; Ikeda, M.; Sato, Y.; Saito, H.; Imai, K.; Isobe, M.; Yamashita, O. Molecular characterization of ovary trehalase of the silkworm, Bombyx mori and its transcriptional activation by diapause hormone. Biochim. Biophys. Acta 1994, 1218, 366-374. [CrossRef]

58. Becker, A.; Schlöder, P.; Steele, J.; Wegener, G. The regulation of trehalose metabolism in insects. Experientia 1996, 52, 433-439. [CrossRef]

59. Shi, Z.K.; Liu, X.J.; Xu, Q.Y.; Qin, Z.; Wang, S.; Zhang, F.; Wang, S.G.; Tang, B. Two novel soluble trehalase genes cloned from Harmonia axyridis and regulation of the enzyme in a rapid changing temperature. Comp. Biochem. Physiol. 2016, 198, 10-18. [CrossRef]

Publisher's Note: MDPI stays neutral with regard to jurisdictional claims in published maps and institutional affiliations.

(C) 2020 by the authors. Licensee MDPI, Basel, Switzerland. This article is an open access article distributed under the terms and conditions of the Creative Commons Attribution (CC BY) license (http://creativecommons.org/licenses/by/4.0/). 